\title{
Overcoming recalcitrant transformation and gene manipulation in Pucciniomycotina yeasts
}

Erika P. Abbott ${ }^{1}$, Giuseppe Ianiri ${ }^{1,2}$, Raffaello Castoria ${ }^{2}$ and Alexander Idnurm ${ }^{1}$ *

${ }^{1}$ Division of Cell Biology and Biophysics, School of Biological Sciences, University of Missouri-Kansas City, USA

${ }^{2}$ Dipartimento di Agricoltura, Ambiente e Alimenti, Facoltà di Agraria, Università del

Molise,Via Francesco De Sanctis, 86100 Campobasso, Italy

* Correspondence:

5100 Rockhill Road

School of Biological Sciences

University of Missouri-Kansas City

Kansas City MO 64110, USA

Phone: +1 8162352265

Email: idnurma@umkc.edu

\section{Abstract}

The red yeasts of the Pucciniomycotina have rarely been transformed with DNA molecules. Transformation methods were recently developed for a species of Sporobolomyces, based on selection using uracil auxotrophs and plasmids carrying the wild type copies of the URA3 and URA5 genes. However, these plasmids were ineffective in the transformation of closely-related species. Using the genome-sequenced strain of Rhodotorula graminis as a starting point, the $U R A 3$ and $U R A 5$ genes were cloned and tested for the transformation ability into different Pucciniomycotina species by biolistic and Agrobacterium-mediated transformations.

Transformation success depended on the red yeast species and the origin of the URA3 or URA5 genes, which may be related to the high $\mathrm{G}+\mathrm{C}$ DNA content found in several species. A new vector was generated to confer resistance to nourseothricin, using a native promoter from $R$. graminis and the naturally high $\mathrm{G}+\mathrm{C}$ nourseothricin acetyltransferease gene. This provides a second selectable marker in these species. Targeted gene disruption was tested in 
Sporobolomyces sp. IAM 13481 using different lengths of homologous DNA with biolistic and Agrobacterium transformation methods. Both DNA delivery methods were effective for targeted replacement of a gene required for carotenoid pigment biosynthesis. The constructs also triggered transgene silencing. These developments open the way to identify and manipulate gene functions in a large group of basidiomycete fungi.

Keywords: basidiomycete; Rhodotorula slooffiae; Rhodosporidium kratochvilovae; $\beta$-carotene; RNAi; T-DNA.

\section{Introduction}

The Pucciniomycotina red yeasts are a paraphyletic assemblage of fungi that are artificially grouped by their morphology, by their capability of producing carotenoid pigments, and by being in the same subphylum within the Basidiomycota phylum. The species are free living and prevalent world wide. They have the potential to serve as models to understand the obligate plant pathogenic rust fungi, which are also members of the Pucciniomycotina. Red yeasts in themselves have been proposed as biocontrol agents, sources of novel enzymes, and in lipid production for biodiesel [for a review and phylogeny of this clade see Aime et al. (2006)]. They can also, in rare cases, cause disease in humans (Tuon and Costa 2008). However, the underlying genetic basis for these interesting properties remains largely unexplored.

Four species of red yeast were used in this study. Sporobolomyces sp. strain IAM 13481 was the first Pucciniomycotina species with a genome sequenced, and was used previously to develop 
plasmids and approaches for gene manipulation (Ianiri et al. 2011). Rhodosporidium kratochvilovae strain LS11 is of interest for biocontrol of fungal pathogens of fruit and degradation of the mycotoxin patulin (Castoria et al. 2003, 2005, 2011; Lima et al. 2005). Its traits underlying biocontrol activity against fungal pathogens of stored fruit have been described at the phenotypic level, but demonstration at the gene level is still missing (Castoria et al. 1997, 2003). $R$. kratochvilovae is of additional research interest from the perspective of the evolution of its mating type locus (Coelho et al. 2010). The interest in Rhodotorula slooffiae relates to the gene duplication of the light-sensing machinery that have occurred in the Pucciniomycotina and Mucoromycotina (Idnurm et al. 2010). Sporobolomyces sp. strain IAM 13481 shows no overt photosensory response. Screening a collection of red yeasts isolated from the San Juan Islands [Washington State, USA; (Fraser et al. 2006)] revealed that pigmentation in $R$. slooffiae strain SJ3 was induced by light. This species is phylogenetically distant from Sporobolomyces sp. IAM 13481 and $R$. kratochvilovae, being in a different subclass within the Pucciniomycotina (Aime et al. 2006; Fell et al. 2000; Valério et al. 2008). The fourth strain is Rhodotorula graminis WP1, isolated as an endophyte from a poplar tree (Xin et al. 2009). This strain fits within a context of genome sequences of a model tree (Populus trichocarpa) and its associated basidiomycete fungi that include a pathogen (Melampsora laricis-populina), mycorrhizal symbiont (Laccaria bicolor) and endophyte (R. graminis). The rationale for using this strain was because its genome had been sequenced, which would aid cloning genes or gene fragments for selectable markers, as well as confirming mutations within auxotrophic strains that could act as the recipients for DNA in transformation experiments. 
In the study of these yeasts, being able to manipulate their genes is essential for understanding genes functions and engineering beneficial traits. Transformation of these species has rarely been reported. The first report was for Rhodosporidium toruloides in the mid-1980s (Tully and Gilbert 1985). We reported methods for transformation of Sporobolomyces sp. strain IAM 13481, by biolistics or Agrobacterium tumefaciens delivery of the DNA (Ianiri et al. 2011). However, we were unable to achieve successful transformation using the same plasmids and transformation approaches on the related red yeast $R$. kratochvilovae strain LS11, which is also within the Sporidiobolales order. Recently, codon-optimized vectors have been used to transform $R$. toruloides (Liu et al. 2012). In this study, we resolve transformation problems in $R$. kratochvilovae and other red yeast species, develop a second selectable dominant marker for transformation, and optimize gene disruption approaches using a species of Sporobolomyces.

\section{Materials and Methods}

\section{Strains and growth conditions}

The strains used or that were generated in this study are listed in Table 1 . The $R$. kratochvilovae strain LS11 was from a collection housed at the University of Molise, Italy. R. slooffiae SJ3 was provided by Drs. Joseph Heitman and James Fraser (Duke University Medical Center, Durham, NC, USA). Sporobolomyces strain IAM 13481 and $R$. graminis strain WP1 were provided by the Fungal Genetics Stock Center (Kansas City, MO, USA). 
Spontaneous uracil auxotrophs were isolated by growth on yeast nitrogen base (YNB) medium supplemented with uracil (20 mg/L) and 5-fluoroorotic acid (1 g/L) (Boeke et al. 1984). Strains were maintained on yeast extract-peptone-dextrose (YPD) medium and preserved as 15\% glycerol stocks at $-80^{\circ} \mathrm{C}$. Media designed for the isolation of lysine and tryptophan auxotrophs was prepared as described previously for Saccharomyces cerevisiae (Chattoo et al. 1979; Toyn et al. 2000).

\section{Construction of plasmids carrying selectable markers for fungal transformation}

The genome sequence database of $R$. graminis WP1, available on the website of the Joint Genome Institute (US Department of Energy; http://genome.jgipsf.org/Rhoba1_1/Rhoba1_1.home.html), was searched by BLAST for the homologs of the $S$. cerevisiae URA3 and URA5 genes. The wild type copies of R. gramins WP1 URA3 and URA5 were amplified from genomic DNA, purified from agarose gel slices and cloned into plasmids TOPO pCR2.1 (Invitrogen, Life Technologies, Grand Island, NY, USA) and subsequently into pPZP-201BK (Covert et al. 2001), as described below.

For the generation of a construct based on a dominant marker, the nourseothricin acetyltransferase (NAT) gene from Streptomyces noursei was chosen (Krügel et al. 1993). To drive the expression of this gene, the promoter and terminator of the $\beta$-tubulin-encoding TUB2 gene of $R$. graminis WP1 were used. To this aim, the genome database of $R$. graminis WP1 was searched by BLAST for the homolog of the TUB2 gene of S. cerevisiae. 790-bp and 508-bp fragments upstream and downstream the ORF region of the TUB2 were amplified from $R$. graminis genomic DNA with primers ALID1614-ALID1615, and ALID1616-ALID1617, 
respectively. The NAT gene was amplified from plasmid pCH233 with primers ALID1618ALID1619. Primer sequences are listed in Table 2. The three products generated by PCR were purified from agarose gel slices and fused together by overlap PCR as previously described (Davidson et al. 2002) to generate the construct $\mathrm{P}_{T U B 2}-N A T-\mathrm{T}_{T U B 2}$. The overlap PCR used primers ALID1614-ALID1617. The NAT construct was purified from an agarose gel slice and cloned into plasmids TOPO pCR2.1 and pPZP-201BK.

For PCR, Ex Taq (Takara, Otsu, Japan) was used to amplify DNA from Sporobolomyces sp. This DNA polymerase enzyme mix and the buffer provided did not amplify DNA fragments from $R$. kratochvilovae strain LS11 or R. graminis strain WP1. Takara's LA Taq, with GC buffer I to improve PCR from high $\mathrm{G}+\mathrm{C}$ content DNA, was used for these two species. Amplifications were performed in a Mastercycler PCR machine (Eppendorf, Hauppauge, NY, USA). For restriction enzyme digests, all enzymes were purchased from New England Biolabs (Ipswich, MA, USA).

Genes or gene fragments were amplified, cloned into plasmid TOPO pCR2.1 and transformed into Escherichia coli strain DH5 $\alpha$ (Invitrogen) cells by heat shock. Transformed E. coli cells were selected on LB medium supplemented with kanamycin $(50 \mu \mathrm{g} / \mathrm{ml})$. Clones that were free from introduction of PCR errors were identified by DNA sequencing. Inserts were subcloned using EcoRI restriction enzyme into plasmid pPZP-201BK, an Agrobacterium binary vector (Covert et al. 2001). Agrobacterium plasmids were transformed into A. tumefaciens strain EHA105 (Hood et al. 1993) by electroporation and selected on LB medium containing kanamycin $(50 \mu \mathrm{g} / \mathrm{ml})$. 
A plasmid was generated that could be transformed into either Sporobolomyces sp. or $S$.

cerevisiae. The URA5 gene of Sporobolomyces sp. IAM 13481 was excised from plasmid pAIS2, and subcloned into the EcoRI site of plasmid pRS426.

A list of the plasmids used for transformation of red yeasts in the study is provided in Table 3.

\section{Fungal transformation}

Transformation of strains followed established protocols for biolistic or Agrobacterium delivery of DNA (Ianiri et al. 2011; Idnurm et al. 2004; Toffaletti et al. 1993). Biolistic transformation was directly on YNB $+1 \mathrm{M}$ sorbitol for the $U R A$ markers, or onto YPD + $1 \mathrm{M}$ sorbitol for the NAT marker, followed by $3 \mathrm{~h}$ recovery at room temperature and transfer to selective YPD + nourseothricin $(200 \mu \mathrm{g} / \mathrm{ml})$ medium. Agrobacterium co-cultures were incubated on induction medium (Bundock et al. 1995) for two or three days prior to transfer to medium to select for transformed fungal strains and cefotaxime to inhibit Agrobacterium growth. The lithium acetate transformation protocol followed that of Ito et al. (1983), of DNA into the recipient Sporobolomyces strain AIS2 or S. cerevisiae strain FY834. Electroporation protocols followed those developed for Cryptococcus neoformans (Edman 1992).

\section{Disruption of the CAR2 gene of Sporobolomyces sp.}

A set of six plasmids was created for disruption of the CAR2 gene of Sporobolomyces sp. Two of these (pEK627 and pPZP627) were designed to deliver a construct with $1 \mathrm{~kb}$ flanking regions, 
while the others carried constructs with $0.5 \mathrm{~kb}(\mathrm{pEK} 5+7$ and pPZP5+7) and $0.25 \mathrm{~kb}(\mathrm{pEK} 6+8$ and pPZP6+8) flanking regions (Table 3).

The construct carrying $1 \mathrm{~kb}$ flanking regions was generated by overlap PCR of three fragments: the 5' flanking region (primers EK001-EK002), the URA5 marker (primers ALID562-ALID564), and the 3' flanking region (primers EK003-EK004). The construct was then purified from an agarose gel slice and cloned into TOPO pCR2.1. After sequencing independent clones, a construct with no errors (pEK627) was generated by subcloning SpeI restriction enzyme fragments. For Agrobacterium-mediated transformation, the insert was subcloned using EcoRI into the binary vector pPZP-201BK; the plasmid (pPZP627) was then transformed into $A$. tumefaciens strain EHA105 before co-incubation with Sporobolomyces sp.

PCR was used to amplify constructs with $0.5 \mathrm{~kb}$ and $0.25 \mathrm{~kb}$ flanking the URA5 gene, off plasmid pEK627 DNA as the template, with primers EK005-EK007 and EK006-EK008, respectively. The products were cloned into TOPO pCR2.1. After sequencing to identify errorfree clones, the plasmids were digested with EcoRI, the fragments of the inserts were purified from agarose gel slices and subcloned into pPZP-201BK for Agrobacterium-mediated transformation. The constructs used for the biolistic transformation were obtained by PCR on pEK627 plasmid DNA, with primers EK005-EK007 and EK006-EK008. The products of the PCR were purified and then used for transformation. 
For the transformation experiments aimed at gene replacement of $C A R 2$, white colonies were characterized by amplification with primers EK009 and EK010. Gene replacement was further confirmed by Southern blot analysis.

\section{Southern blotting}

$2 \mu \mathrm{g}$ of genomic DNA samples were cut with restriction enzymes and resolved on $1 \%$ agarose 1X Tris-acetic acid-EDTA gels. Enzymes used were XhoI and BamHI for the URA3 and URA5 transformants of $R$. slooffiae SJ3-1A and SJ3-2A, respectively; EcoRI and SacII for the URA5 transformants of $R$. graminis EKW10; ClaI for the URA5 transformants of Sporobolomyces AIS2; SacII for URA5 transformants of $R$. kratochvilovae EKLS1; KpnI for the NAT resistant transformants of $R$. graminis WP1 and $R$. kratochvilovae LS11. For the car2 mutants of Sporobolomyces AIS2, genomic DNA was cut with PciI, which cuts once in the middle of the URA5 gene. DNA was transferred by Southern blotting to Zeta-Probe membrane (Bio-Rad, Hercules, CA, USA). The blots were hybridized overnight in modified Church buffer, with [ $\alpha-$

$\left.{ }^{32} \mathrm{P}\right] \mathrm{dCTP}$ probes labeled with the RediPrime II kit (Amersham, GE Healthcare, Piscataway, NJ, USA). Blots were washed with $0.5 \mathrm{x} \mathrm{SSC} / 0.5 \% \mathrm{SDS}$ and stringency at $65^{\circ} \mathrm{C}$, and then exposed to X-ray film. Probes for the $U R A$ genes were amplified by PCR with universal primers M13F and M13R from the plasmids used for transformation. The probe for $C A R 2$ was amplified from genomic DNA of Sporobolomyces sp. with primers EK001-EK004. The NAT probe was prepared by excising it from plasmid pGI1 with EcoRI restriction enzyme.

\section{Resource deposition}


The plasmids containing the $R$. graminis URA genes and NAT cassette, and the $R$. graminis and R. slooffiae uracil auxotrophs were deposited with the Fungal Genetics Stock Center, Kansas City, MO (McCluskey et al. 2010; McCluskey and Wiest 2011). Plasmids can be found via direct search of their names listed in Table 3. For the strains: SJ3 is FGSC 10310, SJ3-1A is FGSC 10311, SJ3-2A is FGSC 10312, EKW15 is FGSC 10313, EKW10 is FGSC 10314, and EKS1 is FGSC 10315.

\section{Results}

Transformation success is variable in the red basidiomycete yeasts and does not follow phylogenetic boundaries

Plasmids containing the URA3 and URA5 genes of Sporobolomyces sp. were tested on $R$. kratochvilovae strain LS11. Stable uracil auxotrophs were isolated from LS11 by selection of spontaneous mutants on 5-fluoroorotic acid (5-FOA), and transformation of the auxotrophs was attempted using biolistic, electroporation, and Agrobacterium delivery of the Sporobolomyces URA3 or URA5 genes. No transformants were obtained with these methods.

After the initial lack of success in transforming $R$. kratochvilovae, these plasmids were tested for transformation of uracil auxotrophs isolated from $R$. slooffiae strain SJ3. Uracil auxotrophs showing resistance to 5-FOA were isolated from strain SJ3 (Fig. 1A). In contrast to $R$. kratochvilovae, transformation was readily achieved for $R$. slooffiae with Agrobacterium for two 
auxotrophs, representing ura3 and ura5 mutations, and the integration of the DNA confirmed by Southern blotting (Fig. 1B).

Next, transformation was tested in $R$. graminis strain WP1. Uracil auxotrophs were isolated using selection on 5-FOA. We were unable to amplify DNA from $R$. graminis strain WP1 with standard Taq DNA polymerase and buffer. DNA amplification was successful using LA Taq (Takara) with a buffer optimized for high $\mathrm{G}+\mathrm{C}$ content DNA. Wild type copies of URA3 and URA5 were amplified from strain WP1, cloned, and error-free clones identified by sequencing. The URA3 and URA5 genes were subcloned into the pPZP-201BK plasmid, to enable their transformation into fungi by Agrobacterium. The URA3 and URA5 genes of the WP1 uracil auxotrophs were amplified and sequenced, revealing mutations in both genes (Fig. 2A). The ura3 mutation is a $\mathrm{C}-\mathrm{T}$ transition that results in a $\mathrm{R}-\mathrm{C}$ substitution at position 12 . This arginine residue is highly conserved in orotidine phosphate decarboxylase proteins. The ura5 mutation is a replacement of four bp with six Ts, causing a frameshift. The origin of this change is unknown, but may be associated with an 8 bp palindrome GGGCGCCC (Fig. 2A).

The vectors derived from Sporobolomyces sp. and $R$. graminis were used in all combinations for transformation into Sporobolomyces sp. IAM 13481 and $R$. graminis WP1 by biolistic and Agrobacterium methods. $R$. graminis could be transformed by biolistic or Agrobacterium delivery of DNA, but only with its copies of the URA3 or URA5 genes, and not those from Sporobolomyces (Fig. 2; Table 4). Southern blot analysis was performed on genomic DNA extracted from untransformed strain EKW10 and eight randomly-selected URA5 transformants generated with Agrobacterium-mediated transformation. DNA was digested with EcoRI (Fig. 
2C, left), which cuts at both borders of the T-DNA, and with SacII (Fig. 2C, right), which does not cut. As expected, a strong 1603-bp hybridization band corresponding to the delivered TDNA-URA5 was obtained for all EcoRI-digested transformants and not in the untransformed strain (Fig. 2C, left). A weak signal to high molecular weight DNA was also detected, presumably corresponding to the native URA5 locus. Hybridization to SacII-digested DNA revealed a common 2102-bp hybridization band of the native URA5 locus for all tested strains, including the untransformed auxotroph. Moreover, for URA5 transformants additional hybridization bands ranging from 3 to $12 \mathrm{~Kb}$, corresponding to the number of T-DNA insertions, were detected (Fig. 2C, right).

In contrast to $R$. graminis, the Sporobolomyces sp. was amenable to transformation by genes from either R. graminis or Sporobolomyces sp., and with both methods (Fig. 3; Table 4) (Ianiri et al. 2011). Phenotypically, URA5 transformants and the ura5 auxotroph AIS2 showed the ability to grow on selective media YNB and 5-FOA, respectively (Fig. 3A). For molecular confirmation, Southern blot analysis was performed on genomic DNA of the untransformed ura5 AIS2 and 11 randomly-selected URA5 transformants generated with both biolistic (lanes 1 - 7) and Agrobacterium-mediated (lanes 8 - 11) transformations (Fig. 3B). DNA was digested with ClaI, which does not cut in the URA5 gene of $R$. graminis WP1. While for the untransformed strain AIS2 there is no hybridization signal, in all selected transformants a single hybridization band is detected, confirming the success of the transformation using as a marker the URA5 gene of $R$. graminis WP1. 
The lithium acetate-PEG heat shock method is commonly applied to ascomycete yeasts (Ito et al. 1983); however Rhodosporidium toruloides is reported as resistant to this transformation approach (Tully and Gilbert 1985). To test this method again, we generated a plasmid (pRS2) that could be transformed into both Sporobolomyces and Saccharomyces. Identical growth conditions and transformation at the same time were used on uracil auxotrophs of both species. Colonies were obtained for S. cerevisiae. No colonies were obtained for Sporobolomyces. Thus, this method is also ineffective on Sporobolomyces.

\section{Successful transformation of $R$. kratochvilovae strain LS11}

With the insight gained from transformation of $R$. graminis, we returned to explore transformation of $R$. kratochvilovae strain LS11. Two uracil auxotrophs of this strain were tested with Agrobacterium and biolistic delivery of the URA3 and URA5 genes from Sporobolomyces or $R$. graminis. As observed previously, the URA3 or URA5 gene of Sporobolomyces could not transform this strain. In contrast, the URA5 gene from $R$. graminis WP1 was able to transform two uracil auxotrophic strains using biolistic or Agrobacterium-mediated delivery of the plasmid or T-DNA (Fig. 4). The strains EKLS1 and EKLS2, that presumably have mutations within the URA5 homolog, showed sensitivity to YNB and also 5-FOA resistance. Conversely, the derived URA5 transformants were able to grow only on YNB. In Fig. 4A the phenotypes observed for strain EKLS1 are shown. For Southern blot confirmation, genomic DNA of the untransformed ura5 auxotroph and 14 randomly-selected URA5 transformants, of which eight were obtained with biolistics (lanes 1 - 8) and six with Agrobacterium-mediated transformation (lanes 9 - 14), was digested with SacII. There is no SacII site in the URA5 gene of R. graminis WP1. 
Hybridization bands ranging from 3 to $15 \mathrm{~Kb}$ were detected, confirming the success of the transformation. For all tested strains, including the untransformed ura5 auxotroph, two faint bands of 1200 and 600 bp were also detected (WT lane in Fig. 4B). We hypothesize that those two bands correspond to the native URA5 gene of $R$. kratochvilovae, which presumably has a SacII site within the ORF.

\section{Development of a new selectable marker for transformation}

One disadvantage in relying on uracil auxotrophs for transformation is the availability of only a single selectable marker. Although the 5-FOA/ura selection system can be recycled, it would be more convenient if a second selectable marker were available. Auxotrophs in the tryptophan and lysine biosynthetic pathways were sought using methods established for $S$. cerevisiae, with the toxic molecules 2-amino-5-fluorobenzoic acid and 2-aminoadipic acid, respectively (Chattoo et al. 1979; Toyn et al. 2000). However, the red yeast strains gained unstable resistance or grew on these media.

The Sporobolomyces sp. strain IAM 13481 also acquires resistance at a high frequency to drugs used for transformation selection in other fungi (Ianiri et al. 2011). However, this was less

evident for $R$. kratochvilovae, $R$. graminis and $R$. slooffiae. Thus, a new vector for expression of nourseothricin acetyltransferase (NAT) was constructed, using the $R$. graminis WP1 $\beta$-tubulin promoter, NAT, and $\beta$-tubulin terminator (Fig. 5A). NAT from the Actinobacteria species Streptomyces noursei is naturally high in G+C content (Krügel et al. 1993). Consistent with the results obtained with the $U R A$ genes of $R$. graminis WP1, this vector was successfully used to 
transform both strains LS11 and WP1 (Fig. 5B, C), but failed in transforming R. slooffiae. For Southern blot analysis, genomic DNA from the wild type strains LS11 and WP1 and from nourseothricin-resistant transformants was digested with KpnI, which cuts twice in the T-DNA and generates a 868-bp fragment (Fig. 5A). As expected, this fragment was detected in all transformants of LS11 (Fig. 5B) and in seven out of nine transformants of WP1 (Fig. 5C). In the two remaining transformants of WP1 probably a deletion at the right border of the T-DNA occurred during integration to remove a $K p n I$ site.

\section{Factors influencing targeted gene replacement of the CAR2 gene in Sporobolomyces}

Targeted gene replacement is a powerful tool to assess the function of a specific gene in the biology of an organism. Previously, the LEU1 gene of Sporobolomyces IAM 13481 was disrupted, by biolistic delivery of a DNA fragment containing 1.5 and $1.0 \mathrm{~kb}$ of DNA specific to the gene placed on either side of the URA3 gene used as the selectable marker (Ianiri et al. 2011). However, in that study, just one transformant was obtained and it was a leul replacement strain. Thus, the efficiency of homologous recombination in relation to DNA length and DNA transformation method was unknown.

The $C A R 2$ gene was chosen for gene replacement in Sporobolomyces sp. CAR2 encodes a bifunctional protein with two domains, catalyzing phytoene synthase and lycopene cyclase as the first and third steps in the biosynthesis of $\beta$-carotene and other carotenoid molecules (Klassen 2010). These pigments give the colonies of the red yeast fungi their characteristic pink, orange 
or red color. The rationale for using this gene was the ability to screen for strains with mutations in $C A R 2$ based upon their white color due to loss of carotenoid pigment production.

Three constructs were generated. These had 1002 bp upstream and 1001 bp downstream, 508 bp upstream and $498 \mathrm{bp}$ downstream, or $255 \mathrm{bp}$ upstream and $248 \mathrm{bp}$ downstream of homologous sequence flanking the URA5 gene (Fig. 6A). The constructs were cloned into plasmid pCR2.1 TOPO, and clones without errors identified by DNA sequencing. Each was excised with EcoRI and subcloned into the EcoRI site of plasmid pPZP-201BK enabling their transformation into a Sporobolomyces ura5 mutant with Agrobacterium.

The use of two transformation methods, i.e. biolistic and Agrobacterium delivery of the DNA, and constructs with different flanking region sizes compared the efficacy of the methods on this organism as measured by the frequency of isolation of white colonies (Fig. 6B). The number of transformed cells is consistently higher with Agrobacterium than with biolistics. For the Agrobacterium transformants, from the construct with $0.5 \mathrm{~kb}$ flanking regions, only 22 white colonies grew on a total of $>2700$ colonies. Moreover, from the construct with $0.25 \mathrm{~kb}$ flanking regions, only one white colony grew on a total of $>5800$ colonies screened, and it was unstable in phenotype. The highest frequencies were achieved with the constructs carrying the $1 \mathrm{~kb}$ flanking regions. The percentage of white colonies versus the total number of colonies was $6 \%$. Similarly, for transformants obtained with biolistic transformation white colonies occurred in $14.5 \%$ of cases. White transformants that were stable in phenotype were further characterized by PCR and Southern blot analysis, confirming that these are gene replacement strains (Fig. 6C, D). 
Although both methods of transformation worked for targeted gene replacement, many of the colonies obtained on selective medium that were initially white were unstable or not complete loss-of-function. These produced colonies with a half pigmented-half white pattern or were pale pink (Fig 6B). PCR and Southern blotting showed that these were not gene disruption strains since the native $C A R 2$ locus was still present (Fig. 6C, D).

\section{Discussion}

In this study we address the challenges in transforming different members of the Pucciniomycotina. The difficulties in this technique have meant that to date just three reports of transformation exist for the red yeasts within this subphylum (Ianiri et al. 2011; Liu et al. 2012; Tully and Gilbert 1985), and an unreported number of failures. In our preliminary studies, multiple attempts of transformation were carried out for $R$. kratochvilovae strain LS11. Negative results were obtained using the genes or their regulatory regions of the Agaricomycotina species C. neoformans and Ustilagomycotina species Ustilago maydis (Idnurm et al. 2004; Marchand et al. 2007; Walton et al. 2005). Surprisingly, R. kratochvilovae strain LS11 could not even be transformed with genes from Sporobolomyces sp. strain IAM 13481 that is also a member of the Pucciniomycotina. On the other hand, plasmids generated from genes cloned from strain IAM 13481 (in subclass Microbotryomycetes) functioned as selectable markers for transforming $R$. slooffiae (which is in subclass Cystobasidiomycetes). It was thus peculiar that the same plasmids were unable to transform $R$. kratochvilovae, and also $R$. graminis, that are classified within the same order (Sporidiobolales). 
Our results indicate that at least two factors restrict transformation success in Pucciniomycotina species. The first is the DNA itself and the second is the recipient species. The URA3 and URA5 genes of $R$. graminis WP1 could transform three strains: $R$. graminis WP1, $R$. kratochvilovae LS11 and Sporobolomyces sp. IAM 13481. Conversely, the URA3 and URA5 genes from Sporobolomyces sp. could not transform the R. graminis or R. kratochvilovae strains. We hypothesize that this is a reflection of $\mathrm{G}+\mathrm{C}$ content for these genes. The promoter regions are sufficient to drive expression in a species (i.e. $R$. slooffiae) in another subclass and $R$. graminis WP1 is intron-rich like Sporobolomyces, excluding transcription or splicing as factors. However, the $\mathrm{G}+\mathrm{C}$ content is dramatically different between these organisms, at $53.8 \%$ for Sporobolomyces sp. IAM 13481 and $67.8 \%$ for $R$. graminis WP1. The G+C content of strain LS11 is unknown. The $\mathrm{G}+\mathrm{C}$ contents reported for $R$. kratochvilovae strains range from $64.7 \%$ to 71.3\% (Hamamoto et al. 1986; Sampaio et al. 2001). Moreover, we cloned and sequenced part of the URA3 gene and surrounding regions from strain LS11: this was $64.9 \% \mathrm{G}+\mathrm{C}$ over $3.2 \mathrm{~kb}$ of sequence (unpublished data). Thus it is reasonable to hypothesize that $R$. kratochvilovae strain LS11 also has a high $\mathrm{G}+\mathrm{C}$ content genome.

The second factor controlling transformation is the species. The Sporobolomyces strain accepted DNA that was high in $\mathrm{G}+\mathrm{C}$ content (i.e. from $R$. graminis), but $R$. graminis could not use the Sporobolomyces genes. Thus, the $\mathrm{G}+\mathrm{C}$ content by itself is not a restriction for transformation success in all species, but is important within the overall genome context of specific strains or lineages within the Pucciniomycotina. 
Our findings corroborate those made recently on $R$. toruloides (Liu et al. 2012). Transformation was initially unsuccessful for these authors. Liu et al. observed a skew in C nucleotides in the wobble codon position of the GPDl gene encoding glyceraldehyde phosphate dehydrogenase, and modified two genes to account for this bias. Use of the GPD1 promoter and a codonoptimized version of the gene encoding hygromycin phosphotransferase enabled successful transformation. Similarly, no expression of the green fluorescent protein (GFP) from the standard coding DNA was achieved, whereas it was with a codon-optimized version.

We compared the codon usage in the two URA genes in both species from which they were cloned. For $R$. graminis WP1, C is used in position $357.8 \%$ of the time, while G is used $35.4 \%$. In contrast, for Sporobolomyces sp. IAM 13481, C is used $36.2 \%$ and $\mathrm{G}$ is used $26.7 \%$. The nourseothricin acetyltransferase gene of Streptomyces noursei that functions in the red yeasts has $\mathrm{C}$ used $56.8 \%$ and $\mathrm{G} 38.0 \%$. Thus, in the Pucciniomycotina whether the limitation in transformation and expression is a reflection of codon usage or $\mathrm{G}+\mathrm{C}$ content, or both, remains to be determined by experiments designed specifically to address these two criteria.

Targeted gene disruption is a vital tool, available by transformation and homologous recombination, to replace DNA regions with selectable markers. The efficiency of sizes of flanking regions was tested in Sporobolomyces sp. IAM 13481 for targeted gene replacement vs. ectopic integrations. Accurate gene replacements were obtained with $\sim 500$ bp or $1 \mathrm{~kb}$ of $C A R 2$ DNA regions on either side of the URA5 selectable marker, whereas none were obtained with $\sim 250$ bp of homologous sequence. Of note, the efficiency of gene disruption may be reduced by 
the targeting of the URA5 gene to its endogenous locus (Fig. S1), as well, in the case of Agrobacterium, delivery of the DNA leading to a high proportion of ectopic integration.

Both the biolistic and Agrobacterium methods were effective at gene replacement in Sporobolomyces sp. Agrobacterium has the advantage of not requiring specialized equipment, unlike the use of a biolistic delivery system. Ascomycete species are amendable to gene replacement by Agrobacterium transformation, but this is not a universal feature of all fungi. For example, the basidiomycete $C$. neoformans does not integrate T-DNA by homologous recombination (McClelland et al. 2005). The disruption of CAR2 in Sporobolomyces sp. represents the first example using Agrobacterium for gene replacement in the Basidiomycota.

A surprising outcome of the gene disruption experiments of $C A R 2$ was the isolation of pale and/or unstable white strains from both transformation approaches. The silencing of transgenes has been reported in other fungi, with parallels between the unstable white transformants of Sporobolomyces with the silencing of the al-1 and al-3 genes in Neurospora crassa, leading to the discovery of "quelling" mediated by RNA interference (Catalanotto et al. 2002; Romano and Macino 1992). RNA silencing is used in basidiomycetes as an experimental system to repress gene expression, including in the Pucciniomycotina (Lawrence et al. 2010). There are few reports of inadvertent silencing of transformed genes in basidiomycete species (Wang et al. 2012). While the mechanisms that control silencing in Sporobolomyces are currently undefined, this trait may represent a useful property for experimental studies to silence expression of genes in this or other red yeasts species. 
For R. kratochvilovae, a strain is now available with two selectable markers for transformation. We predict that the recently developed $P_{G P D 1}-h p t-3$ construct would also function as a third selectable marker to confer resistance to hygromycin (Liu et al. 2012). Strain LS11 is also fertile to the extent of producing filaments and teliospores with a strain of opposite mating type, potentially providing the experimental benefits of Mendelian genetics (Sampaio et al. 2001).

The fungal species that are best-studied at the molecular level can have their DNA manipulated with ease; many other species have never been tested for transformation or are a challenge thereby limiting the feasibility for experiments. The approaches presented here, i.e., identification of an auxotroph and use of the original gene sequence introduced by a variety of transformation methods, may be more widely applicable to these species.

\section{Acknowledgments}

We thank Joseph Heitman, James Fraser, and the FGSC for providing strains. This research was supported by grants from the United States National Science Foundation (MCB-0920581), the Italian Ministry of Education, University and Scientific Research (PRIN 2008, 2008JKH2MM), and the Italian Ministry of Foreign Affairs (joint research project LS-7, within the executive programme of cooperation in the field of science and technology between Italy and U.S.A. 20082010). G. I. was also supported by a scholarship from the Department of Agricultural, Environmental and Food Sciences, University of Molise, Italy.

\section{References}


Aime MC, Matheny PB, Henk DA, Frieders EM, Nilsson RH, Piepenbring M, McLaughlin DJ, Szabo LJ, Begerow D, Sampaio JP, Bauer R, Weiß M, Oberwinkler F, Hibbett D (2006) An overview of the higher level classification of Pucciniomycotina based on combined analyses of nuclear large and small subunit rDNA sequences. Mycologia 98:896-905

Boeke JD, LaCroute F, Fink GR (1984) A positive selection for mutants lacking orotidine-5'phosphate decarboxylase activity in yeast: 5-fluoro-orotic acid resistance. Mol Gen Genet 197:345-346

Bundock P, den Dulk-Ras A, Beijersbergen A, Hooykaas PJJ (1995) Trans-kingdom T-DNA transfer from Agrobacterium tumefaciens to Saccharomyces cerevisiae. EMBO J $14: 3206-3214$

Castoria R, De Curtis F, Lima G, De Cicco V (1997) $\beta$-1,3-glucanase activity of two saprophytic yeasts and possible mode of action involved as biocontrol agents against postharvest diseases. Postharvest Biol Technol 12:293-300

Castoria R, Caputo L, De Curtis F, De Cicco V (2003) Resistance of postharvest biocontrol yeasts to oxidative stress: a possible new mechanism of action. Phytopathology 93:564572

Castoria R, Morena V, Caputo L, Panfili G, De Curtis F, De Cicco V (2005) Effect of the biocontrol yeast Rhodotorula glutinis strain LS11 on patulin accumulation in stored apples. Phytopathology 95:1271-1278

Castoria R, Mannina L, Durán-Patrón R, Maffei F, Sobolev AP, De Felice DV, Pinedo-Rivilla C, Ritieni A, Ferracane R, Wright SAI (2011) Conversion of the mycotoxin patulin to the less toxic desoxypatulinic acid by the biocontrol yeast Rhodosporidium kratochvilovae strain LS11. J Agric Food Chem 59:11571-11578

Catalanotto C, Azzalin G, Macino G, Cogoni C (2002) Involvement of small RNAs and role of the qde genes in the gene silencing pathway in Neurospora. Genes Dev 16:790-795

Chattoo BB, Sherman F, Azubalis DA, Fjellstedt TA, Mehnert D, Ogur M (1979) Selection of lys 2 mutants of the yeast Saccharomyces cerevisiae by the utilization of $\alpha$-aminoadipate. Genetics 93:51-65

Coelho MA, Sampaio JP, Gonçalves P (2010) A deviation from the bipolar-tetrapolar mating paradigm in an early diverged basidiomycete. PLoS Genet 6:e1001052

Covert SF, Kapoor P, Lee M-H, Briley A, Nairn CJ (2001) Agrobacterium tumefaciens-mediated transformation of Fusarium circinatum. Mycol Res 105:259-264

Davidson RC, Blankenship JR, Kraus PR, de Jesus Berrios M, Hull CM, D'Souza C, Wang P, Heitman J (2002) A PCR-based strategy to generate integrative targeting alleles with large regions of homology. Microbiology 148:2607-2615

Edman JC (1992) Isolation of telomere-like sequences from Cryptococcus neoformans and their use in high-efficiency transformation. Mol Cell Biol 12:2777-2783

Fell JW, Boekhout T, Fonseca A, Scorzetti G, Statzell-Tallman A (2000) Biodiversity and systematics of basidiomycetous yeasts as determined by large-subunit rDNA D1/D2 domain sequence analysis. Int J Syst Evol Microbiol 50:1351-1371

Fraser JA, Lim SM, Diezmann S, Wenink EC, Arndt CG, Cox GM, Dietrich FS, Heitman J (2006) Yeast diversity sampling on the San Juan Islands reveals no evidence for the spread of the Vancouver Island Cryptococcus gattii outbreak to this locale. FEMS Yeast Res 6:620-624 
Hamamoto M, Sugiyama J, Komagata K (1986) DNA base composition of strains in the genera Rhodosporidium, Cystofilobasidium, and Rhodotorula determined by reverse-phase high performance liquid chromatograph. J Gen Appl Microbiol 32:215-223

Hood ME, Gelvin SB, Melchers LS, Hoekema A (1993) New Agrobacterium helper plasmids for gene transfer to plants. Transgenic Res 2:208-218

Ianiri G, Wright SAI, Castoria R, Idnurm A (2011) Development of resources for the analysis of gene function in Pucciniomycotina red yeasts. Fungal Genet Biol 48:685-695

Idnurm A, Reedy JL, Nussbaum JC, Heitman J (2004) Cryptococcus neoformans virulence gene discovery through insertional mutagenesis. Eukaryot Cell 3:420-429

Idnurm A, Verma S, Corrochano LM (2010) A glimpse into the basis of vision in the kingdom Mycota. Fungal Genet Biol 47:881-892

Ito H, Fukuda Y, Murata K, Kimura A (1983) Transformation of intact yeast cells treated with alkali cations. J Bacteriol 153:163-168

Klassen JL (2010) Phylogenetic and evolutionary patterns in microbial carotenoid biosynthesis are revealed by comparative genomics. PLoS ONE 5:e11257

Krügel H, Fiedler G, Smith C, Baumberg S (1993) Sequence and transcriptional analysis of the nourseothricin acetyltransferase-encoding gene nat 1 from Streptomyces noursei. Gene 127:127-131

Lawrence GJ, Dodds PN, Ellis JG (2010) Transformation of the flax rust fungus, Melampsora lini: selection via silencing of an avirulence gene. Plant J 61:364-369

Lima G, Spina AM, Castoria R, De Curtis F, De Cicco V (2005) Integration of biocontrol agents and food-grade additives for enhancing protection of stored apples from Penicillium expansum. J Food Prot 68:2100-2106

Liu Y, Koh CMJ, Sun L, Hlaing MM, Du M, Peng N, Ji L (2012) Characterization of glyceraldehyde-3-phosphate dehydrogenase gene RtGPD1 and development of genetic transformation method by dominant selection in oleaginous yeast Rhodosporidium toruloides. Appl Microbiol Biotechnol:DOI:10.1007/s00253-012-4223-9

Marchand G, Fortier E, Neveu B, Bolduc S, Belzile F, Bélanger RR (2007) Alternative methods for genetic transformation of Pseudozyma antarctica, a basidiomycetous yeast-like fungus. J Microbiol Methods 70:519-527

McClelland CM, Chang YC, Kwon-Chung KJ (2005) High frequency transformation of Cryptococcus neoformans and Cryptococcus gattii by Agrobacterium tumefaciens. Fungal Genet Biol 42:904-913

McCluskey K, Wiest A, Plamann M (2010) The Fungal Genetics Stock Center: a repository for 50 years of fungal genetics research. J Biosci 35:119-126

McCluskey K, Wiest A (2011) The Fungal Genetics Stock Center in the context of a world wide community of ex situ fungal germplasm repositories. Fungal Biol Rev 25:143-150

Romano N, Macino G (1992) Quelling: transient inactivation of gene expression in Neurospora crassa by transformation with homologous sequences. Mol Microbiol 6:3343-3353

Sampaio JP, Gadanho M, Santos S, Duarte FL, Pais C, Fonseca A, Fell JW (2001) Polyphasic taxonomy of the basidiomycetous yeast genus Rhodosporidium: Rhodosporidium kratochvilovae and related anamorphic species. Int J Syst Evol Microbiol 51:687-697

Toffaletti DL, Rude TH, Johnston SA, Durack DT, Perfect JR (1993) Gene transfer in Cryptococcus neoformans by use of biolistic delivery of DNA. J Bacteriol 175:14051411 
Toyn JH, Gunyuzlu PL, White WH, Thompson LA, Hollis GF (2000) A counterselection for the tryptophan pathway in yeast: 5-fluoroanthranilic acid resistance. Yeast 16:553-660

Tully M, Gilbert HJ (1985) Transformation of Rhodosporidium toruloides. Gene 36:235-240

Tuon FF, Costa SF (2008) Rhodotorula infection. A systematic review of 128 cases from literature. Rev Iberoam Micol 25:135-140

Valério E, Gadanho M, Sampaio JP (2008) Reappraisal of the Sporobolomyces roseus species complex and description of Sporidiobolus metaroseus sp. nov. Int J Syst Evol Microbiol 58:736-741

Walton FJ, Idnurm A, Heitman J (2005) Novel gene functions required for melanization of the human pathogen Cryptococcus neoformans. Mol Microbiol 57:1381-1396

Wang X, Wang P, Sun S, Darwiche S, Idnurm A, Heitman J (2012) Transgene induced cosuppression during vegetative growth in Cryptococcus neoformans. PLoS Genet 8:e1002885

Winston F, Dollard C, Ricupero-Hovasse SL (1995) Construction of a set of convenient Saccharomyces cerevisiae strains that are isogenic to S288C. Yeast 11:53-55

Xin G, Glawe D, Doty SL (2009) Characterization of three endophytic, indole-3-acetic acidproducing yeasts occurring in Populus trees. Mycol Res 113:973-980

Yamazaki M, Komagata K (1983) An electrophoretic comparison of enzymes of ballistosporogenous yeasts. J Gen Appl Microbiol 29:115-143

\section{Figure legends}

Fig. 1 Transformation of $R$. slooffiae with genes from Sporobolomyces sp. A. Phenotypes of wild type, uracil auxotrophs SJ3-1A and SJ3-2A, and the same auxotrophs transformed with Agrobacterium T-DNA with cloned URA3 or URA5 genes from Sporobolomyces sp. Strains were 10-fold serially-diluted and spotted onto YNB \pm uracil \pm 5 -FOA. B. Southern blots on DNA from untransformed auxotroph (WT), three ura3 + URA3 transformants (1-3), and three ura5 + URA5 transformants (4-6), probed with the URA3 gene (left) or URA5 gene (right). The probes were amplified from the full length fragments used in the plasmids for transformation. DNA was digested with XhoI for the URA3 transformants and with BamHI for the URA5 transformants. Both enzymes cut in the middle of the delivered DNA molecule. 
Fig. 2 Transformation of $R$. graminis with genes from $R$. graminis using uracil auxotrophs as recipient strains. A. Position (black line) and type of mutation in the ura3 and ura5 strains, EKW15 and EKW10, isolated from strain WP1 that were used for transformation. The altered DNA sequence is indicated below in bold. B. Phenotypes of wild type, ura5 uracil auxotroph, and a transformed strain. Strains were 10-fold serially-diluted and spotted onto YNB \pm uracil \pm 5-FOA. C. Southern blot of auxotroph EKW15 (WT) and nine strains transformed with Agrobacterium T-DNA. Genomic DNA was digested with EcoRI (left), which cuts at the borders of delivered DNA, and SacII (right), which does not cut within the T-DNA. The probe was the full length URA5 fragment cloned into the transformation plasmid. The common band of 1603 bp obtained for EcoRI-digested DNA is the exogenous URA5 inserted by the transformation. Weak hybridization with high molecular weight DNA indicates low efficiency transfer during blotting of the fragment containing the endogenous URA5 gene. The common band of 2012-bp obtained for SacII-digested DNA is the original URA5 locus.

Fig. 3 Transformation of Sporobolomyces sp. with the R. graminis URA5 gene. A. Phenotypes of the wild type, ura5 uracil auxotroph and a transformed strain. Strains were 10-fold seriallydiluted and spotted onto YNB \pm uracil \pm 5 -FOA. B. Southern blot of auxotroph AIS2 (WT) and 11 transformed strains DNA samples cut with ClaI, which does not cut in the delivered DNA. The probe was the fragment including URA5 cloned into the plasmid for transformation. Lanes 1 - 7 are strains generated with biolistics, and lanes 8 - 11 are strains generated with Agrobacterium-mediated transformation. 
Fig. 4 Transformation of auxotroph EKLS1 of $R$. kratochvilovae with the R. graminis URA5 gene. A. Phenotypes of the wild type, ura5 uracil auxotroph and a transformed strain. Strains were 10-fold serially-diluted and spotted onto YNB \pm uracil \pm 5 -FOA. B. Southern blot of auxotroph EKLS1 (WT) and 14 transformed strains. DNA samples were digested with SacII, which does not cut within the delivered DNA. Lanes 1 - 8 are strains generated with biolistics, and lanes 9 - 14 are strains generated with Agrobacterium-mediated transformation. The two common faint bands of 1200 and $600 \mathrm{bp}$, marked by the asterisks, may correspond to the native ura5 gene of $R$. kratochvilovae because the URA5 probe hybridizes to them in the untransformed strain (WT).

Fig. 5 Development of a new selectable marker for transformation of R. kratochvilovae and $R$. graminis. A. Map of the $\mathrm{P}_{T U B 2}-N A T-\mathrm{T}_{T U B 2}$ construct in the T-DNA. B. and C. Transformed plates of $R$. kratochvilovae strain LS11 (B) and R. graminis strain WP1 (C) on YPD \pm nourseothricin. The left plates are the untransformed controls. Southern blots of $R$. kratochvilovae and $R$. graminis wild type (WT) and Agrobacterium T-DNA transformants. Genomic DNA was digested with KpnI, which cuts twice in the T-DNA and generates a 868-bp fragment that is detected with the probe that spans the entire NAT construct.

Fig. 6 Disruption of the CAR2 gene of Sporobolomyces sp. A. Diagrams of the native locus of $C A R 2$, disruption cassettes, and situation after gene replacement. CAR2 exons are in orange. The URA5 ORF is the white arrow, with surrounding DNA in black. Primers used for creating the constructs are drawn as arrows. B. Pigmentation phenotypes of wild type (WT), two car2 replacement strains via Agrobacterium $(\Delta A)$ and biolistic $(\Delta \mathrm{B})$ transformations, and unstable 
strain EKS4 (unst.) growing on YNB medium. C. PCR analysis with primers EK009-EK010 of wild type, two gene disruption strains from biolistic and Agrobacterium delivery of the DNA, and one transformed strain showing a silencing phenotype. D. Southern blot of DNA isolated from the four strains. DNA was digested with $P$ ciI and probed with the wild type CAR2 gene amplified with primers EK001-EK004. 


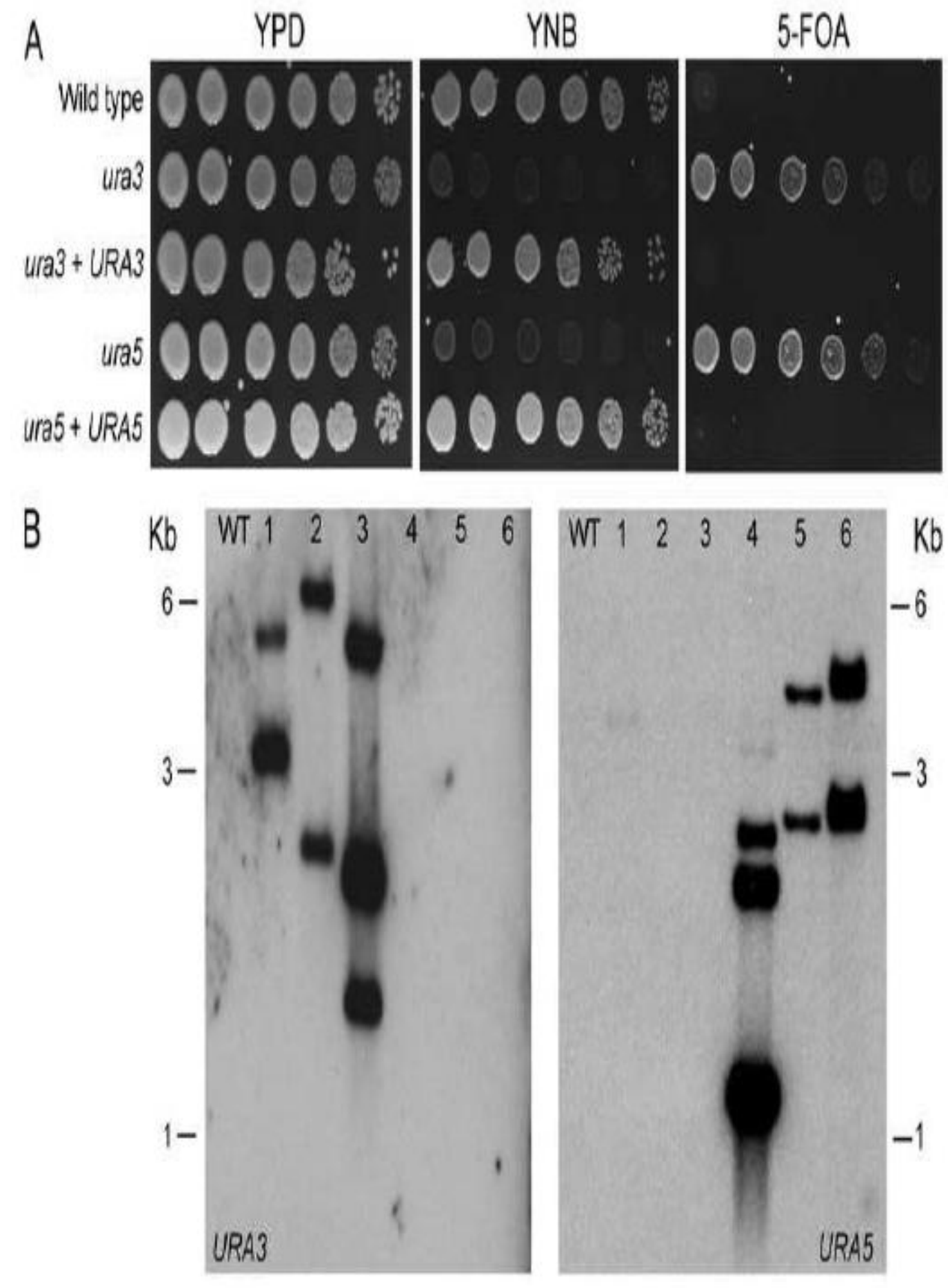




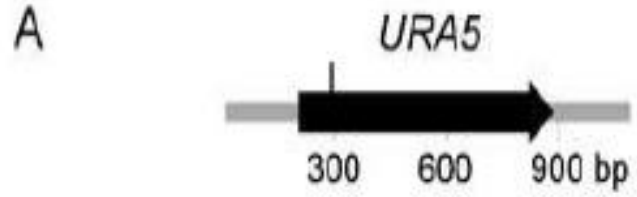

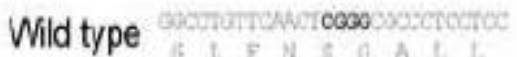

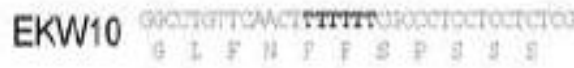

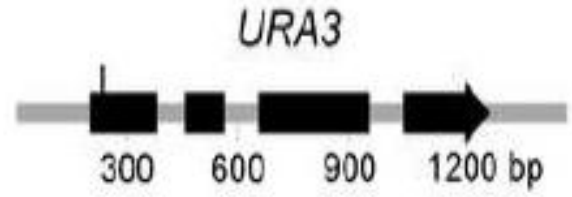

Wild type thowactocescosoriot

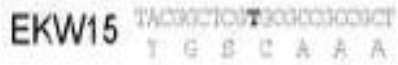
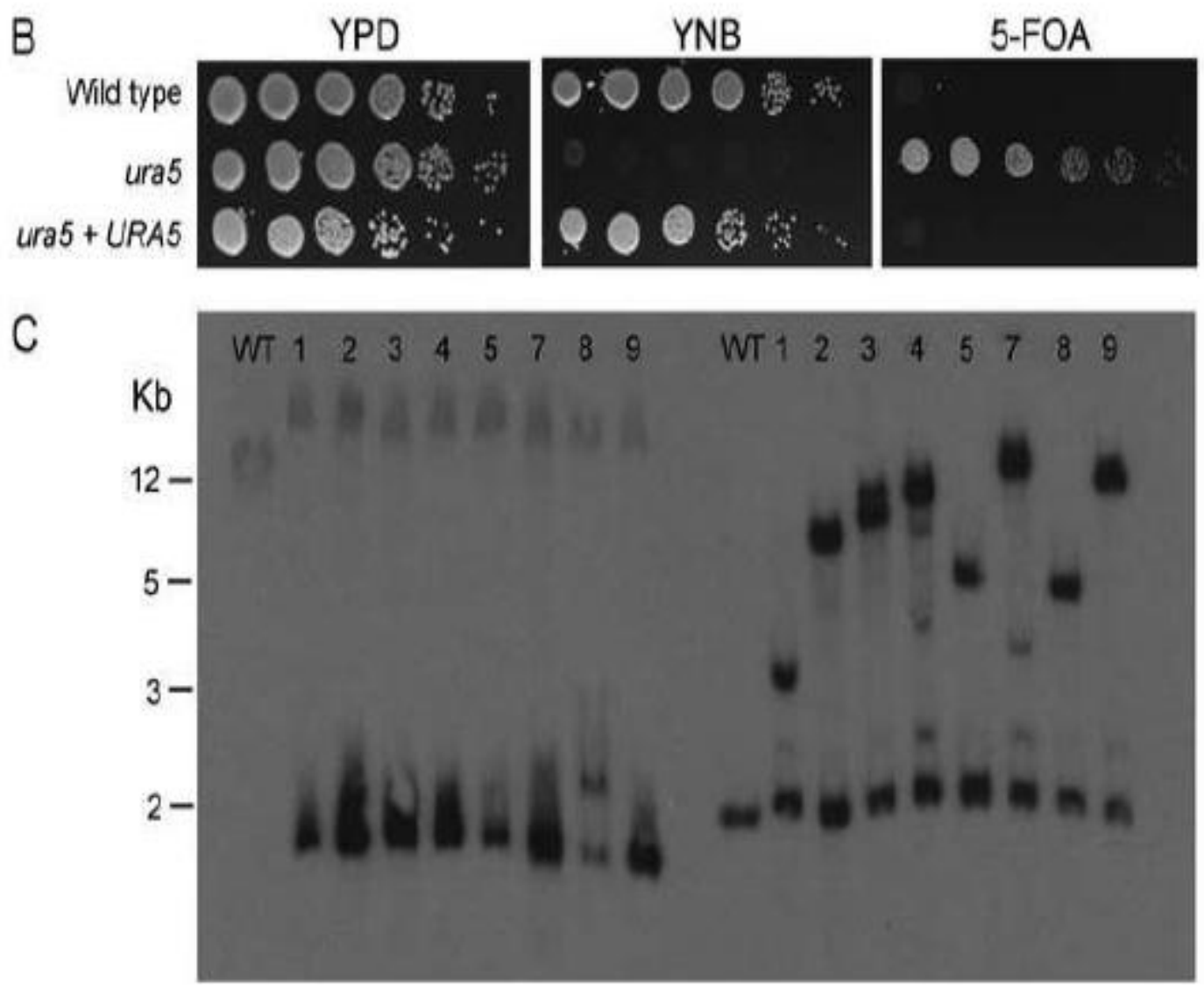


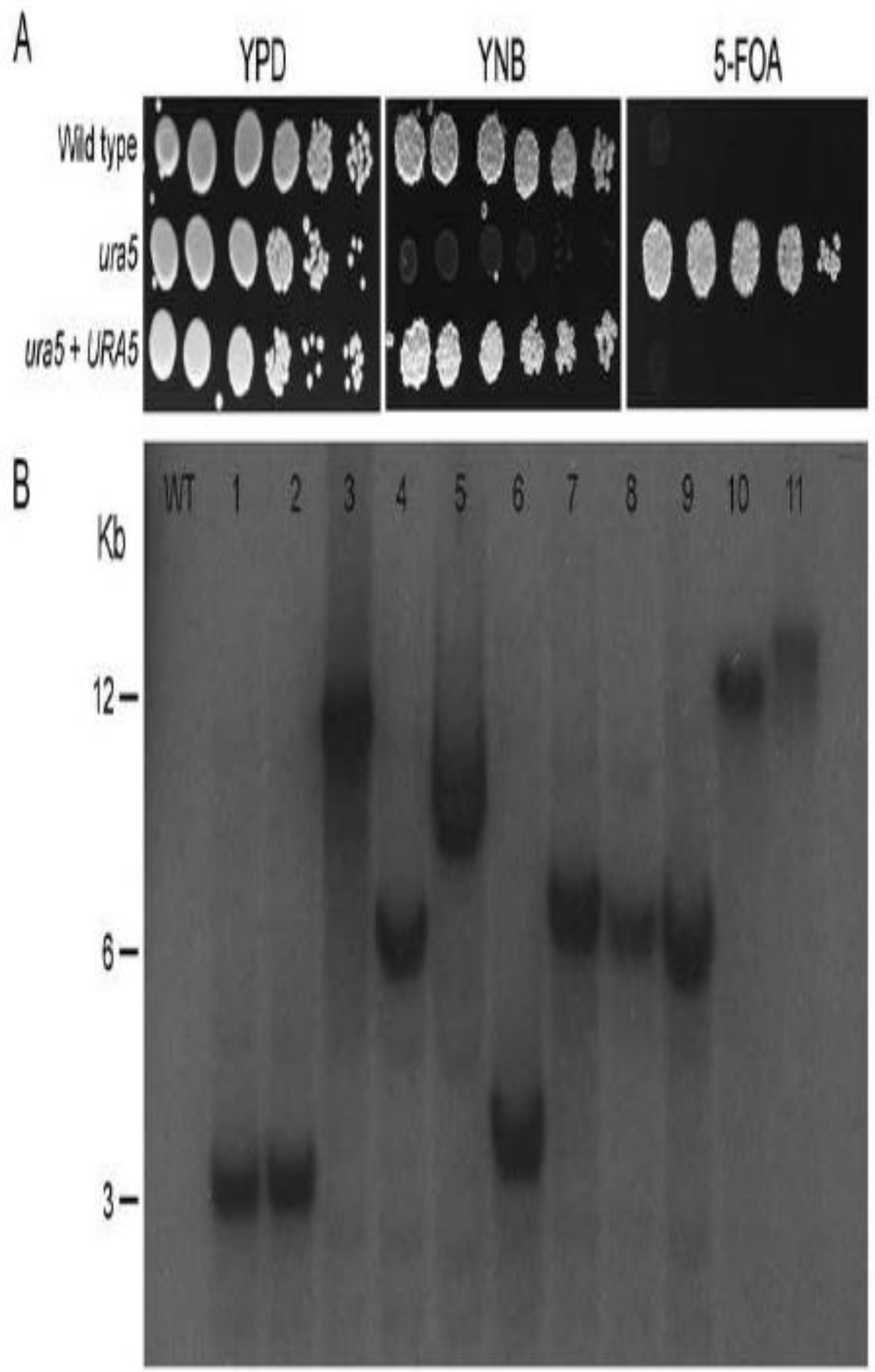




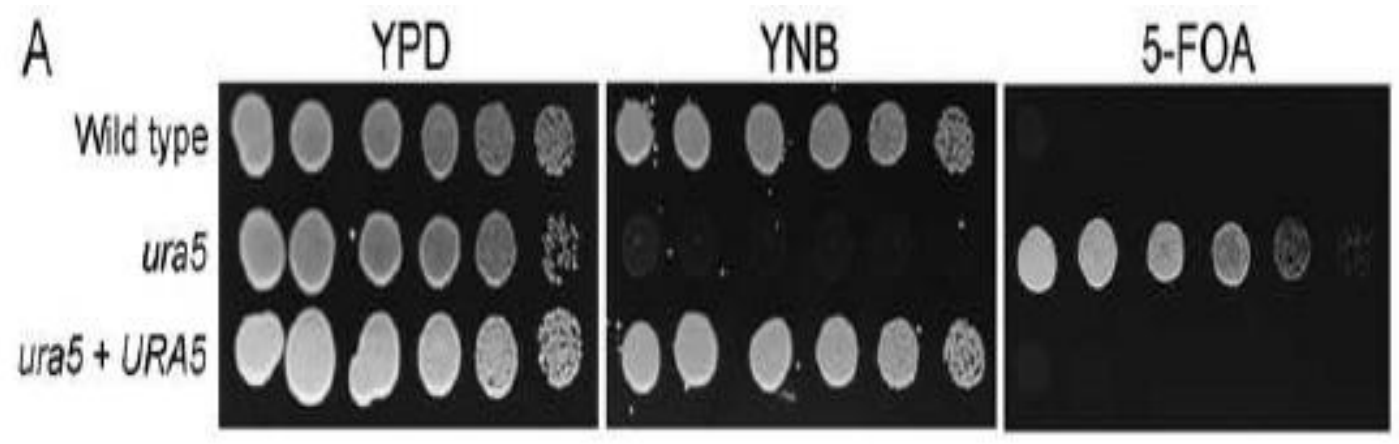

B

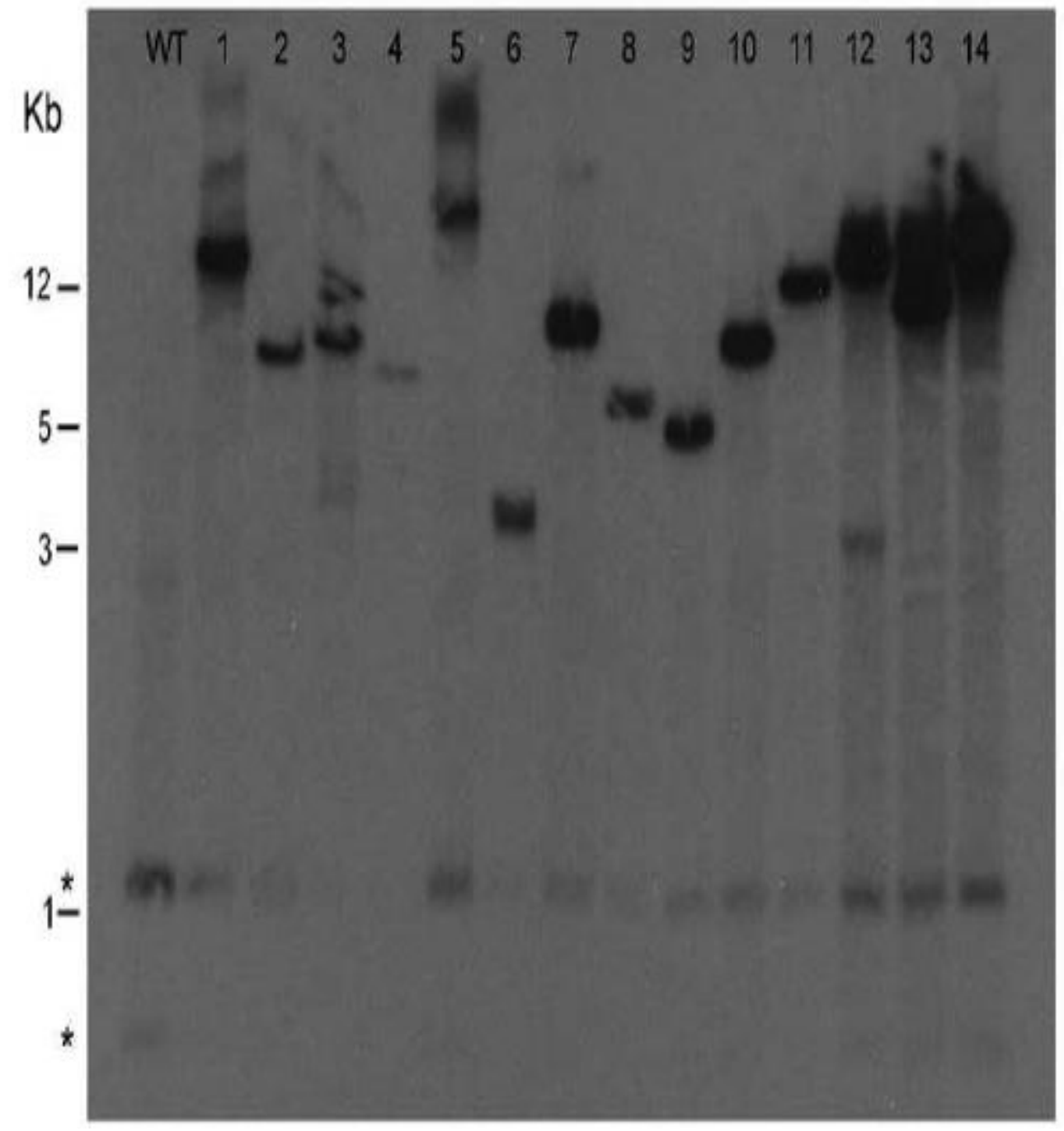




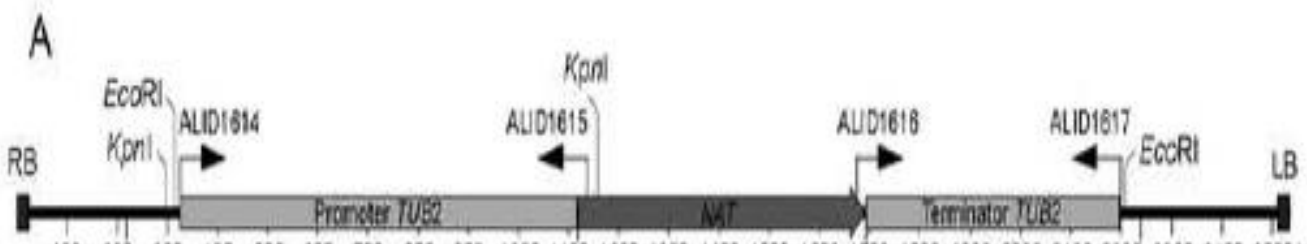

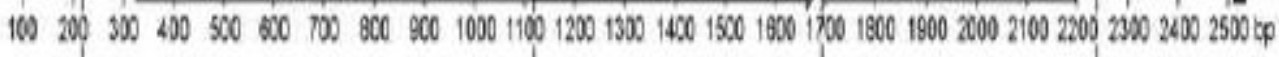
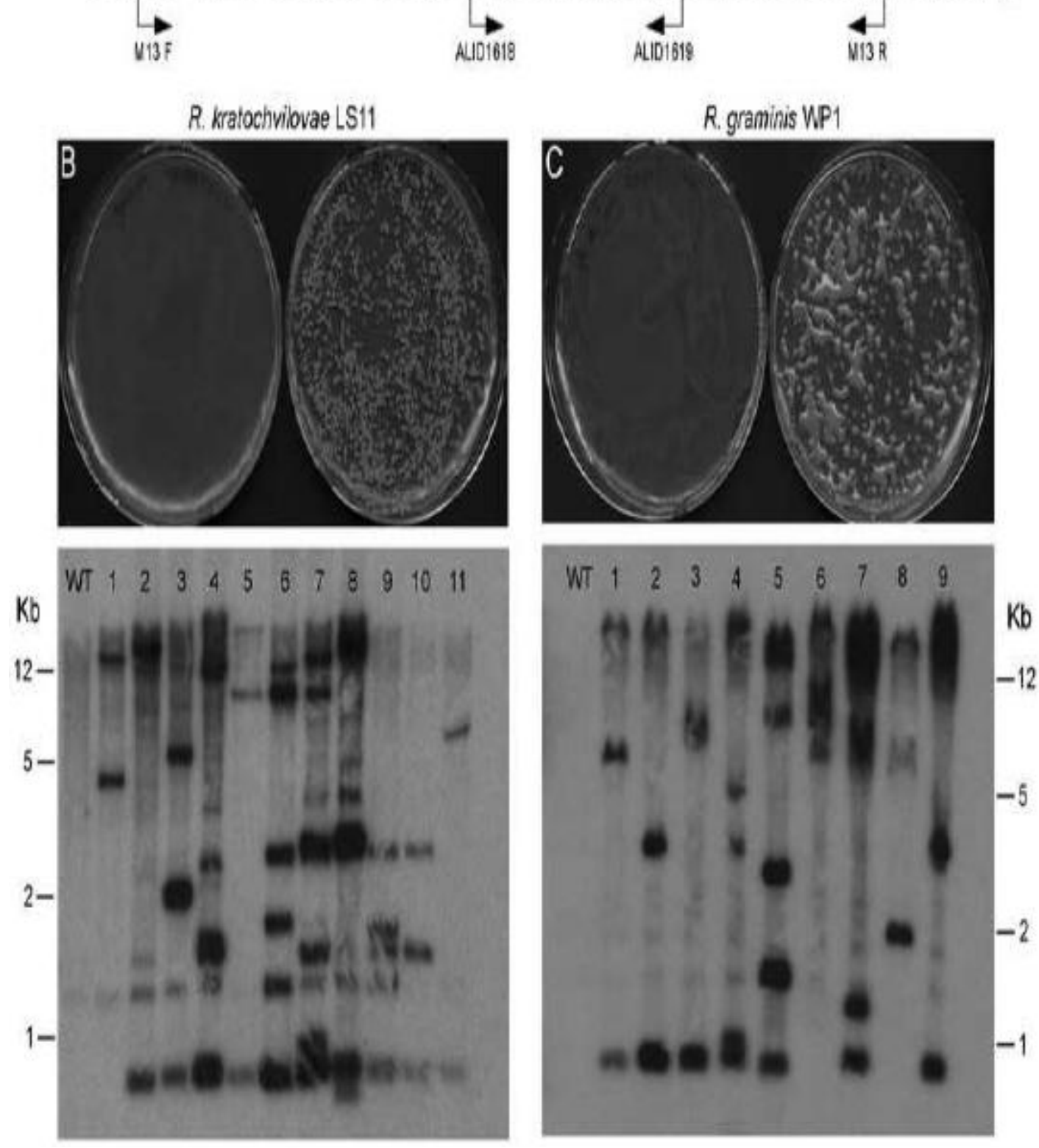
A

WT

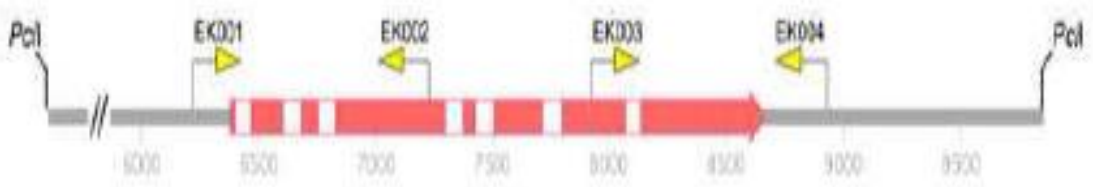

$\Delta$ constructs
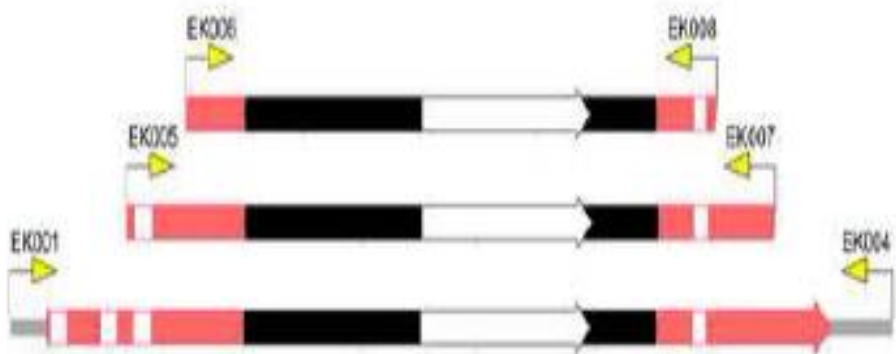

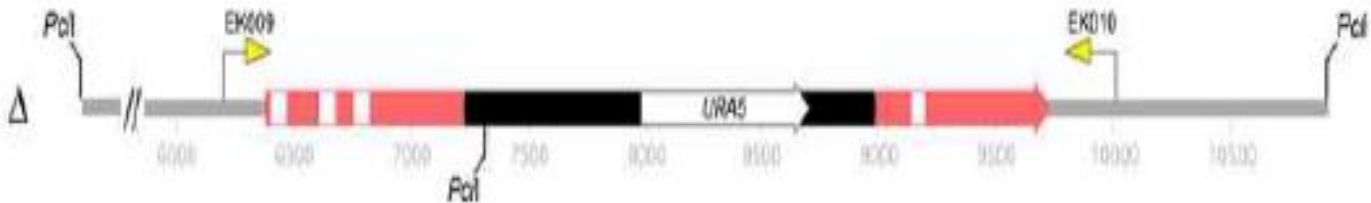
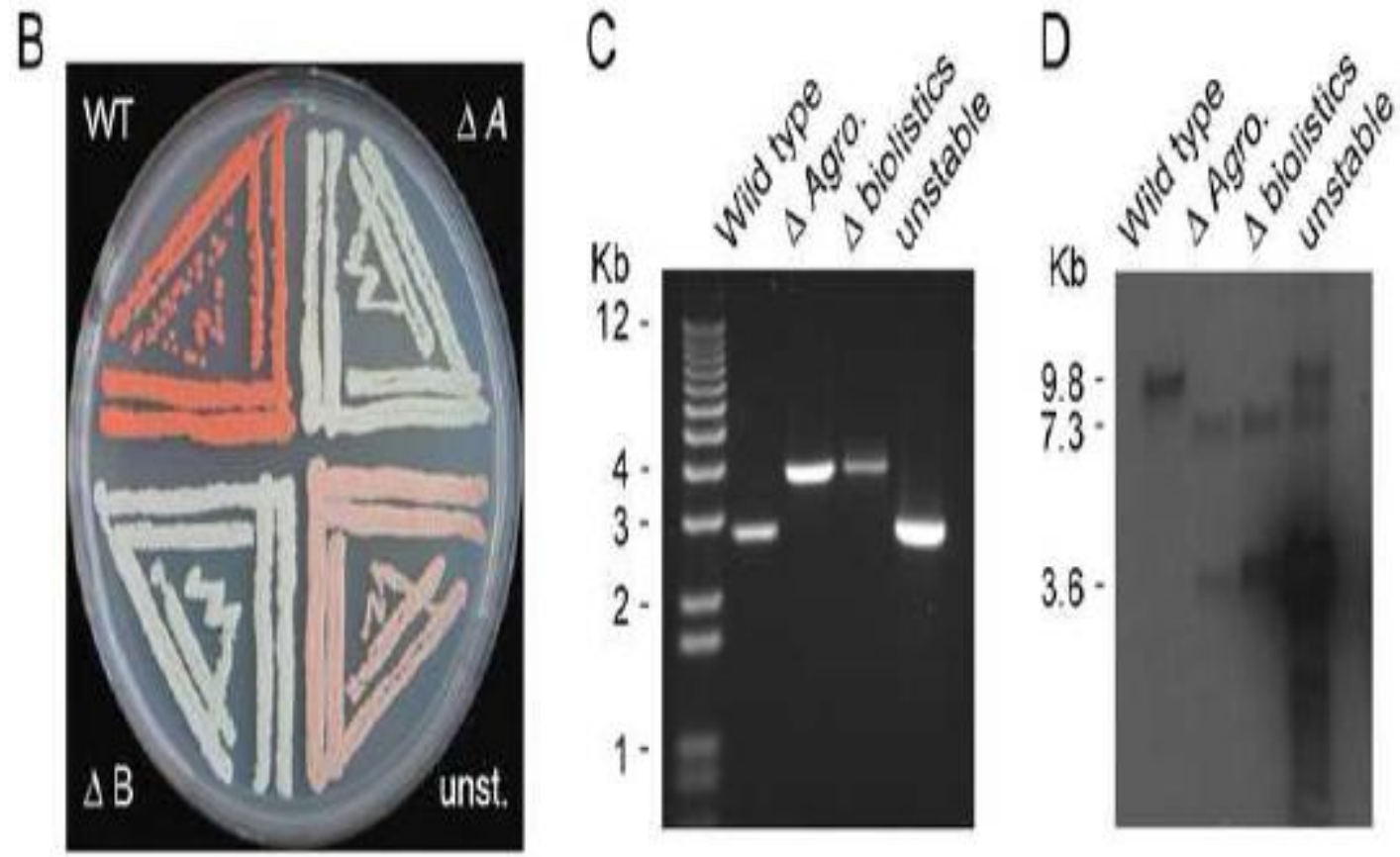


\section{A}
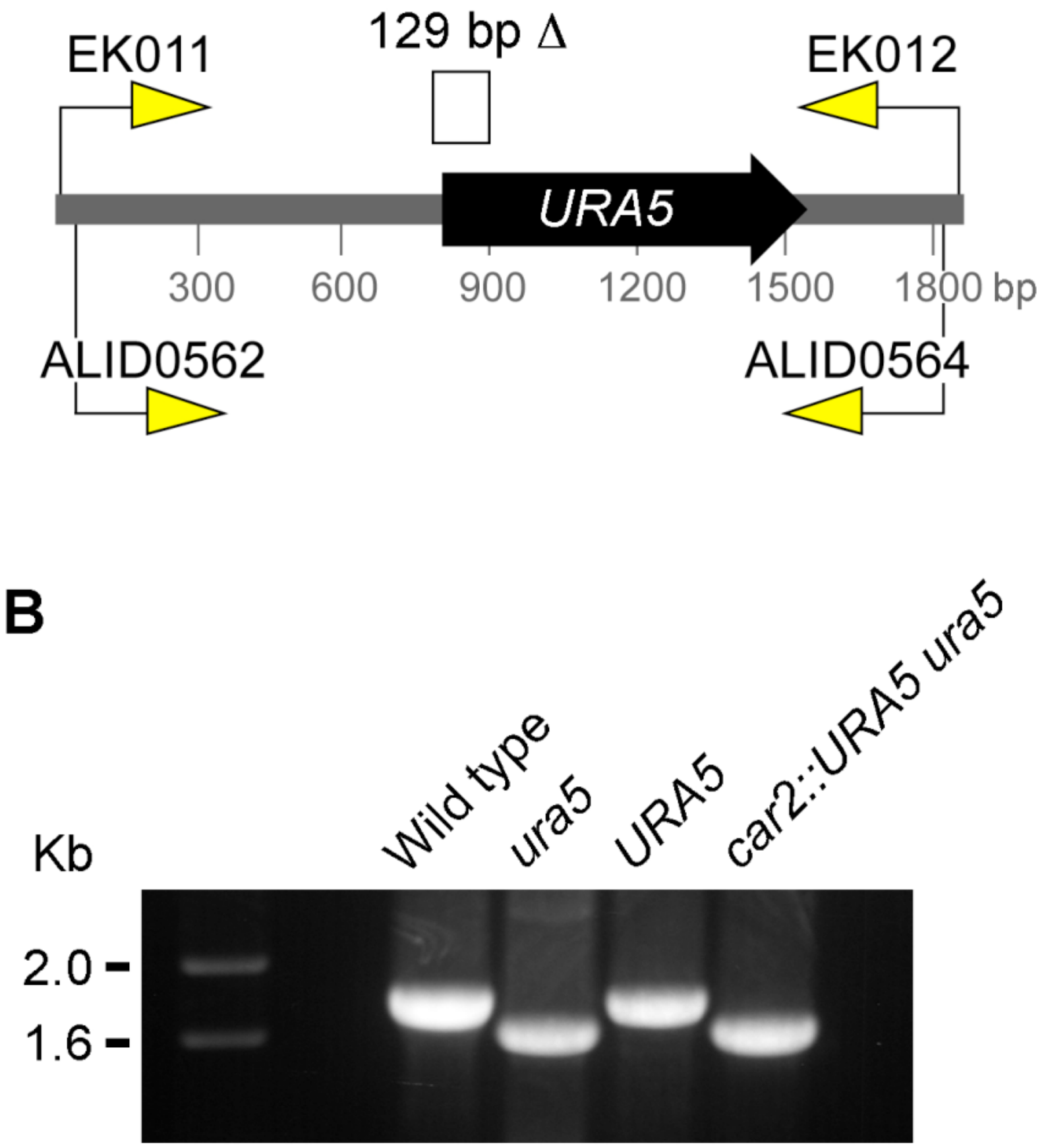

Fig. S1 Example of homologous recombination of the URA5 selectable marker into the native URA5 locus. A. Diagram of the primers relative to the coding region of the URA5 gene. Primers ALID0562-ALID564 were used to amplify the region for inclusion in the car2::URA5 disruption cassette. Primers EK001 and EK012 are on either side of this region. The position of the $129 \mathrm{bp}$ 
deletion $(\Delta)$ in ura5 strain AIS2 is indicated as a white box. B. Agarose gel resolving the PCR products from four strains amplified with primers EK011-EK012. The ura5 strain (AIS2) was transformed with the car2::URA5 construct by biolistics. The URA5 strain has undergone a homologous replacement of the ura5 mutant region. The car2::URA5 ura5 strain (EKS2) has undergone a homologous replacement of the $C A R 2$ gene, and maintains the original ura5 mutant allele.

Table 1 Strains used in this study.

\begin{tabular}{|c|c|c|c|}
\hline Name & Genotype & Strain background & Reference \\
\hline $\begin{array}{l}\text { Sporobolomyces sp. } \\
\text { IAM } 13481\end{array}$ & Wild type & & $\begin{array}{l}\text { Yamazaki and } \\
\text { Komagata (1983) }\end{array}$ \\
\hline AIS1 & ura3 & IAM 13481 & Ianiri et al. (2011) \\
\hline AIS2 & ura5 & IAM 13481 & Ianiri et al. (2011) \\
\hline EKS1 & car2::URA5 ura5 & $\begin{array}{l}\text { AIS2 } \\
\text { Agrobacterium }\end{array}$ & This study \\
\hline EKS2 & car2::URA5 ura5 & AIS2 biolistic & This study \\
\hline EKS3 & $\begin{array}{l}\text { car2::URA5 ura5 } \\
\text { car2 unstable }\end{array}$ & $\begin{array}{l}\text { AIS2 } \\
\text { Agrobacterium }\end{array}$ & This study \\
\hline EKS4 & $\begin{array}{l}\text { car2::URA5 ura5 } \\
\text { car } 2 \text { unstable }\end{array}$ & AIS2 biolistic & This study \\
\hline $\begin{array}{l}\text { Rhodotorula } \\
\text { graminis } \mathrm{WP1}\end{array}$ & Wild type & & Xin et al. (2009) \\
\hline EKW15 & ura3 & WP1 & This study \\
\hline EKW10 & ura5 & WP1 & This study \\
\hline $\begin{array}{l}\text { Rhodotorula } \\
\text { slooffiae SJ3 }\end{array}$ & Wild type & & Fraser et al. (2006) \\
\hline SJ3-1A & ura3 & SJ3 & This study \\
\hline SJ3-2A & ura5 & $\mathrm{SJ} 3$ & This study \\
\hline $\begin{array}{l}\text { Rhodosporidium } \\
\text { kratochvilovae } \\
\text { LS11 }\end{array}$ & Wild type & & Lima et al. (1998) \\
\hline EKLS1 & ura5 & LS11 & This study \\
\hline EKLS2 & ura5 & LS11 & This study \\
\hline $\begin{array}{l}\text { Saccharomyces } \\
\text { cerevisiae FY834 }\end{array}$ & $\begin{array}{l}\text { MAT } \alpha \text { his } 3 \Delta 200 \\
\text { ura3-52 leu } 2 \Delta 1 \\
\text { lys } 2 \Delta 202 \text { trp } 1 \Delta 63\end{array}$ & & $\begin{array}{l}\text { Winston et al. } \\
\text { (1995) }\end{array}$ \\
\hline
\end{tabular}


Table 2 Primers used in this study. Nucleotides are listed 5' to 3'. The italicized nucleotides indicate regions that overlap other primers. Restriction enzyme sites introduced for subcloning are underlined.

\begin{tabular}{|c|c|c|}
\hline Name & Sequence (5'-3') & $\begin{array}{l}\text { Purpose/gene } \\
\text { amplified }\end{array}$ \\
\hline EK001 & GGAATTCGGGTGTAGATCGATTCAGAG & \multirow{2}{*}{$\begin{array}{l}\text { Sporobolomyces } \\
\text { CAR2 5' flank }\end{array}$} \\
\hline EK002 & GGTCTTTCCAGGGAGAGACGCATCGCATTCCCAGAG & \\
\hline EK003 & CAAGTAGAACGAAGGGTTAGCTTCACACCCTCGTAG & \multirow{2}{*}{$\begin{array}{l}\text { Sporobolomyces } \\
\text { CAR2 3' flank }\end{array}$} \\
\hline EK004 & GGAATTCATCCGCTTACTGTCAAGGAG & \\
\hline EK005 & AACAGGCCACCATACCCTG & \multirow{2}{*}{$\begin{array}{l}\text { CAR2 } 500 \text { bp } \\
\text { flanking }\end{array}$} \\
\hline EK007 & GCGTCGACGGGTCGACCAG & \\
\hline EK006 & CTCCCGACCAAAGCCGAAC & \multirow{2}{*}{$\begin{array}{l}\text { CAR2 250 bp } \\
\text { flanking }\end{array}$} \\
\hline EK008 & CTTGATCCGTTTGAATCGG & \\
\hline EK009 & AATCCGTTCTCATCCAGG & \multirow{2}{*}{$\begin{array}{l}\text { Confirming } \\
\text { CAR2 gene } \\
\text { replacement }\end{array}$} \\
\hline EK010 & CTTCGCTTCTCACCAATC & \\
\hline EK011 & CGGAACGAGACAGAAGAAGC & \multirow{2}{*}{$\begin{array}{l}\text { Assessing } \\
\text { integration in } \\
\text { URA5 locus }\end{array}$} \\
\hline EK012 & ATCCCTCGCGTCTGCGAGTG & \\
\hline ALID0562 & TCTCTCCCTGGAAAGACC & \multirow{2}{*}{$\begin{array}{l}\text { Sporobolomyces } \\
\text { URA5 }\end{array}$} \\
\hline ALID0564 & AACCCTTCGTTCTACTTG & \\
\hline ALID1164 & CACTGCTTTACGCCGACCTG & \multirow{2}{*}{$\begin{array}{l}\text { R. graminis } \\
\text { URA5 }\end{array}$} \\
\hline ALID1165 & TCGAGAAGGTCGACTTGAGC & \\
\hline ALID1281 & AGCGCCTCGGTGAAAGTG & \multirow{2}{*}{$\begin{array}{l}\text { R. graminis } \\
\text { URA3 }\end{array}$} \\
\hline ALID1282 & TTCGGGCTCACGACGCTC & \\
\hline ALID1614 & GCGACGACGTGTGGGGCTACC & \multirow{2}{*}{$\begin{array}{l}\text { R. graminis } \beta- \\
\text { tubulin } \\
\text { promoter }\end{array}$} \\
\hline ALID1615 & AAGAGTGGCGGCCGCCATCGTGGCTTGCGGGAGTGG & \\
\hline ALID1616 & AGCATGCCCTGCCCCTAAGCTTATTCACCTGCACTC & \multirow{2}{*}{$\begin{array}{l}\text { R. graminis } \beta \text { - } \\
\text { tubulin } \\
\text { terminator }\end{array}$} \\
\hline ALID1617 & TCTCGCGAGCGAGGTTGGC & \\
\hline ALID1618 & ATGGCGGCCGCCACTCTTGACG & \multirow{2}{*}{ NAT gene } \\
\hline ALID1619 & TTAGGGGCAGGGCATGCTCATG & \\
\hline
\end{tabular}


Table 3 Plasmids used in this study.

\begin{tabular}{|c|c|c|}
\hline Name & Features & Reference/source \\
\hline pAIS1 & Sporobolomyces sp. URA3 in TOPO pCR 2.1 & Ianiri et al. (2011) \\
\hline pAIS2 & Sporobolomyces sp. URA5 in TOPO pCR2.1 & Ianiri et al. (2011) \\
\hline pAIS3 & Sporobolomyces sp. URA3 in pPZP-201BK & Ianiri et al. (2011) \\
\hline pAIS4 & Sporobolomyces sp. URA5 in pPZP-201BK & Ianiri et al. (2011) \\
\hline pEK627 & car $2:: U R A 5$ overlap in TOPO pCR2.1 $(1 \mathrm{~kb})$ & This study \\
\hline pEK5+7 & car $2:: U R A 5$ overlap in TOPO pCR2.1 (500 bp) & This study \\
\hline pEK6+8 & car $2:: U R A 5$ overlap in TOPO pCR2.1 (250 bp) & This study \\
\hline pPZP627 & car $2:: U R A 5$ overlap in pPZP-201BK & This study \\
\hline pPZP5+7 & car $2:: U R A 5$ overlap in pPZP-201BK & This study \\
\hline pPZP6+8 & car $2: \because U R A 5$ overlap in pPZP-201BK & This study \\
\hline pEKWU3 & R. graminis WP1 URA3 in TOPO pCR2.1 & This study \\
\hline pEKWU5 & $R$. graminis WP1 URA5 in TOPO pCR2.1 & This study \\
\hline pPZPWU3 & R. graminis WP1 URA3 in pPZP-201BK & This study \\
\hline pPZPWU5 & R. graminis WP1 URA5 in pPZP-201BK & This study \\
\hline pRS2 & Sporobolomyces sp. URA5 in pRS426 & This study \\
\hline pGI1 & $\mathrm{P}_{T U B 2}-N A T-\mathrm{T}_{T U B 2}$ in TOPO pCR2.1 & This study \\
\hline pGI2 & $\mathrm{P}_{T U B 2}-N A T-\mathrm{T}_{T U B 2}$ in pPZP-201BK & This study \\
\hline
\end{tabular}

Table 4 Summary of transformation results.

\begin{tabular}{|l|c|c|c|c|}
\cline { 2 - 5 } \multicolumn{1}{l|}{} & \multicolumn{4}{c|}{ DNA source/transformation method } \\
\hline Strain & $\begin{array}{l}\text { Sporobolomyces } \\
\text { sp./ biolistics }\end{array}$ & $\begin{array}{l}\text { Sporobolomyces } \\
\text { sp./ } \\
\text { Agrobacterium }\end{array}$ & $\begin{array}{l}\text { R. graminis/ } \\
\text { biolistics }\end{array}$ & $\begin{array}{l}\text { R. graminis/ } \\
\text { Agrobacterium }\end{array}$ \\
\hline $\begin{array}{l}\text { Sporobolomyces } \\
\text { sp. }\end{array}$ & Yes & Yes & Yes & Yes \\
\hline R. slooffiae & Yes & Yes & No & No \\
\hline R. graminis & No & No & Yes & Yes \\
\hline $\begin{array}{l}\text { R. } \\
\text { kratochvilovae }\end{array}$ & No & No & Yes & Yes \\
\hline
\end{tabular}




\section{University Library}

\section{- M M I N E R VA A gateway to Melbourne's research publications}

Minerva Access is the Institutional Repository of The University of Melbourne

Author/s:

Abbott, EP;laniri, G;Castoria, R;Idnurm, A

Title:

Overcoming recalcitrant transformation and gene manipulation in Pucciniomycotina yeasts

Date:

2013-01-01

Citation:

Abbott, E. P., laniri, G., Castoria, R. \& Idnurm, A. (2013). Overcoming recalcitrant transformation and gene manipulation in Pucciniomycotina yeasts. APPLIED MICROBIOLOGY AND BIOTECHNOLOGY, 97 (1), pp.283-295. https://doi.org/10.1007/ s00253-012-4561-7.

Persistent Link:

http://hdl.handle.net/11343/282823 